\title{
Antiproliferative activity and possible mechanism of action of certain 5-methoxyindole tethered C-5 functionalized isatins
}

This article was published in the following Dove Press journal:

Drug Design, Development and Therapy

\author{
Maha S Almutairi ${ }^{1}$ \\ Eman S Hassan ${ }^{2}$ \\ Adam B Keeton ${ }^{3}$ \\ Gary A Piazza ${ }^{3}$ \\ Ali S Abdelhameed' \\ Mohamed I Attia ${ }^{\text {I, }}$ \\ 'Department of Pharmaceutical \\ Chemistry, College of Pharmacy, King \\ Saud University, Riyadh I I45I, Saudi \\ Arabia; ${ }^{2}$ Department of Medical \\ Laboratory Sciences, Al-Ghad \\ International Medical Sciences College, \\ Female Section, Riyadh 13315, Saudi \\ Arabia; ${ }^{3}$ Department of Oncologic \\ Sciences and Pharmacology, Drug \\ Discovery Research Center, Mitchell \\ Cancer Institute, University of South \\ Alabama, Mobile, AL 36604-I405, USA; \\ ${ }^{4}$ Medicinal and Pharmaceutical Chemistry \\ Department, Pharmaceutical and Drug \\ Industries Research Division, National \\ Research Centre (ID: 600I46I8), Giza \\ 12622, Egypt
}

Background: Cancer is one of the most dreaded human diseases, that has become an everincreasing health problem and is a prime cause of death globally. The potential antiproliferative activity of certain indole-isatin molecular hybrids 5a-w was evaluated in vitro against three human cancer cell lines.

Methods: Standard protocols were adopted to examine the antiproliferative potential and mechanisms of compounds 5a-w. Western blot analysis was carried out on compound $\mathbf{5 0 .}$

Results: Compounds 5a-w demonstrated in vitro antiproliferative activity in the range of 22.6-97.8\%, with compounds $\mathbf{5 0}$ and $\mathbf{5 w}$ being the most active antiproliferative compounds with $\mathrm{IC}_{50}$ values of 1.69 and $1.91 \mu \mathrm{M}$, which is fivefold and fourfold more potent than sunitinib $\left(\mathrm{IC}_{50}=8.11 \mu \mathrm{M}\right)$, respectively. Compound 50 was selected for in-depth pharmacological testing to understand its possible mechanism of antiproliferative activity. It caused a lengthening of the $\mathrm{G} 1$ phase and a reduction in the $\mathrm{S}$ and $\mathrm{G} 2 / \mathrm{M}$ phases of the cell cycle and had an $\mathrm{IC}_{50}$ value of $10.4 \mu \mathrm{M}$ with the resistant NCI-H69AR cancer cell line. Moreover, compound 50 significantly decreased the amount of phosphorylated Rb protein in a dosedependent fashion, which was confirmed via Western blot analysis.

Conclusion: The current investigation highlighted the potential antiproliferative activity of compounds 5a-w as well as the antiproliferative profile of compound 50. These compounds can be harnessed as new lead antiproliferatives in the preclinical studies of cancer chemotherapy.

Keywords: isatin, indole, synthesis, antiproliferative, apoptosis

\section{Introduction}

Cancer is one of the most terrifying diseases of humanity and has become a fundamental health problem and a principal cause of death globally. One in four deaths in the United States is a result of cancer. ${ }^{1}$ More than ten million new cases of cancer occur every year, approximately half of which occur in developed countries, with the disease causing more than six million deaths every year. ${ }^{2-4}$ A molecularly targeted approach has recently been utilized for the management of disseminated cancer which depends on the study of oncogenes and tumor suppressors which are involved in the emergence of human cancers. ${ }^{5}$ Consequently, there has been an advancement in the specificity of cancer management, progressing from the use of general cytotoxic agents such as nitrogen mustard in the 1940s, the development of chemotherapeutic agents such as anthracyclines and Vinca alkaloids from natural resources in the 1960 s and finally the use of specific monoclonal antibodies ${ }^{6}$ and
Correspondence: Mohamed I Attia Department of Pharmaceutical Chemistry, College of Pharmacy, King Saud University, P.O. Box. 2457, Riyadh

II45I, Saudi Arabia

Tel +966 | 4677337

Fax +966 I 4676220

Email mattia@ksu.edu.sa 
specific chemotherapeutic agents which inhibit protein tyrosine kinases (PTKs) as advanced approaches. ${ }^{7-9}$ These targeted chemotherapeutic agents usually attenuate signaling pathways which control the cancer cell cycle and alter its microenvironment, blocking tumor cell proliferation, cell apoptosis and/or hindering tumor mass growth. ${ }^{10}$ These developments led to a reduction of anticancer side effects and ameliorated the response rate. Therefore, the study of the mechanisms by which cancers resist chemotherapeutic agents gave rise to a deep understanding of the reasons for the failure of cancer therapies.
Indole (I, Figure 1) is a privileged bicyclic structure which was first synthesized in 1866. The indole scaffold is incorporated into a large number of biologically active molecules endowed with a wide range of bioactivities and is naturally occurring in Vinca and ergot alkaloids, fungal metabolites and marines. ${ }^{11}$ In recent years, indole and its functionalized derivatives have been embedded in myriad bioactive pharmaceuticals including anti-inflammatories, analgesics, antimicrobials and antitumors. ${ }^{12-18}$ Furthermore, 5-methoxyindole is the fundamental fragment in the natural hormone melatonin (MLT, II, Figure 1). MLT and its derivatives have a broad spectrum of<smiles>c1ccc2[nH]ccc2c1</smiles>

I<smiles>COc1ccc2[nH]cc(CCNC(C)=O)c2c1</smiles>

II<smiles>O=C1Nc2ccccc2C1=O</smiles>

III<smiles>[X]c1ccc2c(c1)/C(=N/NC(=O)c1cc3cc(OC)ccc3[nH]1)C(=O)N2[R]</smiles>

5a-w

Figure I Chemical structures of compounds I-III and 5a-w.

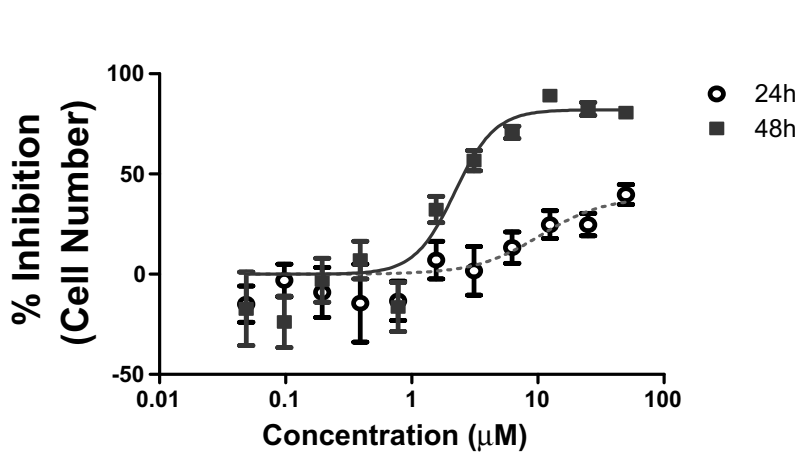

50

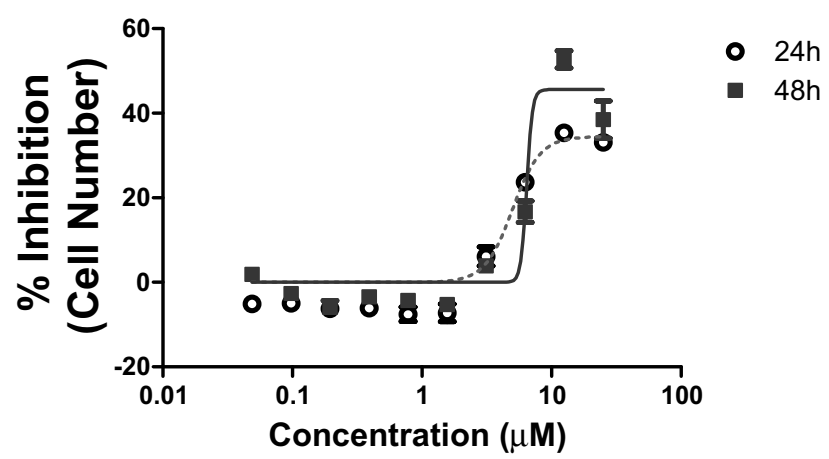

Sunitinib

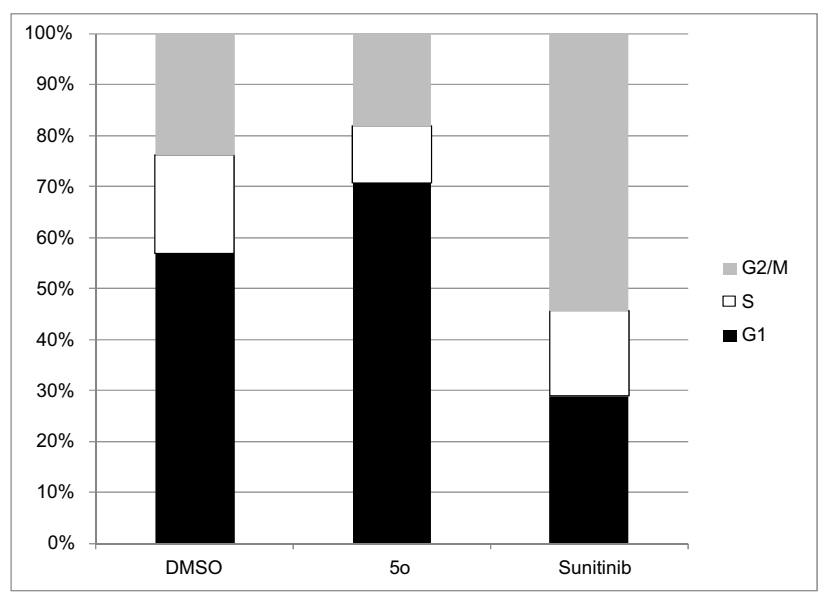

Figure 2 Cell cycle influences of compound 50 after incubation for 24 and 48 hrs. 
pharmaceutical applications, particularly for the treatment of headache, depression and sleep disorders, and for the management of certain types of cancer. ${ }^{19}{ }^{21}$

On the other hand, isatin (2,3-dioxindole, III) is considered an oxidized form of indole and has been recognized to be an endogenous multifunctional molecule in human beings and other mammals. ${ }^{22}$ The special electronic properties of isatin along with its proper molecular size give rise to several different valuable biological characteristics. Therefore, isatin was embedded into the backbone of various bioactive molecules including anticonvulsants, ${ }^{23}$ antifungals, $^{24}$ antibacterials, ${ }^{25}$ anti-HIV agents ${ }^{24,26}$ and anticancer agents. ${ }^{27}{ }^{31}$

According to the aforementioned premises, it was our interest to prepare the indole-isatin conjugates $\mathbf{5 a - w}$ as hybrid molecules tailored from indole and isatin pharmacophore fragments for biological evaluation. The isatin moiety of the target conjugates $\mathbf{5 a - w}$ is functionalized on their C-5 position and bears various $N$-aralkyl substitutions that alter the electronic and lipophilic environment, allowing us to explore their impact on the biological activity of compounds 5a-w. Compounds 5a-wdisplayed moderate antimicrobial potential. ${ }^{32,33}$ The current report deals with the assessment of their in vitro antiproliferative potential. The most active antiproliferative candidates were subjected to deep pharmacological testing to gain insight into the possible mechanism of their antiproliferative activity.

\section{Materials and methods Chemistry}

5-Methoxy-1H-indole-2-carbohydrazide (3) - The acid hydrazide 3 was prepared from the corresponding ester $2^{34}$ using the documented method. ${ }^{32}$ It has a melting point (m.p.) of $266-268^{\circ} \mathrm{C}$.

\section{General method for the preparation of 5-methoxy- $\mathrm{IH}$-indole-2-carbo hydrazide derivatives $5 \mathrm{a}-\mathrm{w}$}

Glacial acetic acid (catalytic amount) was added to a mixture of the proper isatin derivative 4a-n $(1 \mathrm{mmol})$ and the acid hydrazide $3(1 \mathrm{mmol})$ in absolute ethyl alcohol $(15 \mathrm{~mL})$. The reaction mixture was then stirred under reflux for $4 \mathrm{hrs}$. The precipitated solid was filtered while hot, and the obtained solid was recrystallized from an ethyl alcohol/dimethylformamide mixture (3:1) to furnish the corresponding compounds 5a-w in 43-94\% yields. The analytical data of compounds 5a-w are previously documented. ${ }^{32,33}$

\section{Pharmacological evaluation}

Pharmacological assessment of the title compounds including antiproliferative activity, selectivity, cell cycle effects and quantitative immunofluorescence of $\mathbf{5 a - w}$ was performed with previously documented methods. ${ }^{29}$ Western blot analysis of total cellular proteins enabled detection of $\mathrm{P}-\mathrm{Rb}$ and GAPDH (glyceraldehyde-3-phosphate dehydrogenase) using antibodies obtained from Cell Signaling Technology (Boston, MA, USA). Western blots were imaged by direct imaging of chemiluminescent blots (ChemiDoc Imaging System; BioRad, Hercules, CA, USA). Quantitation was carried out using NIH ImageJ public domain image analysis software. The cell lines were purchased commercially from the American Type Culture Collection (ATCC).

\section{Results and discussion}

\section{Chemistry}

Compounds 5a-w were prepared as illustrated in Scheme 1. Thus, the commercially available 5-methoxy indole-2-carboxylic acid (1) was esterified in absolute methanol and a catalytic amount of concentrated sulfuric acid, followed by hydrazinolysis, to prepare the hydrazide 3. Subsequently, compound 3 was reacted with the isatin derivatives $4 a-n^{33}$ to achieve the respective title compounds $\mathbf{5 a - w}$ in moderate yields.

\section{Pharmacological investigations Antiproliferative activity}

The isatin nucleus is incorporated into various anticancer candidates. $^{28,29,31,35,36}$ The preliminary antiproliferative potential of compounds 5a-w was tested using A-549 (lung), HT-29 (colon) and ZR-75 (breast) human cancer cell lines, and the obtained data are presented in Table 1. Sunitinib was used against the same human cancer cell lines as a reference drug for the experiments. The results are expressed as an average percent growth inhibition at $30 \mu \mathrm{M}$ concentration for each compound tested in quadruplicate. The title compounds $\mathbf{5 a - w}$ exhibited an average growth inhibition of $22.6-97.8 \%$ in the antiproliferative assay against the tested human cancer cell lines, except for compound 5e, which stimulated the growth of the ZR-75 cell line. It seems that the $N$-unsubstituted isatin (compounds $\mathbf{5 b}$ and $\mathbf{5 c}$ ), $N$-methyl (compounds $\mathbf{5 g}$-i), $N$-benzyl (compound 5o) or $N$-phenyl (compound 5w) moieties are 


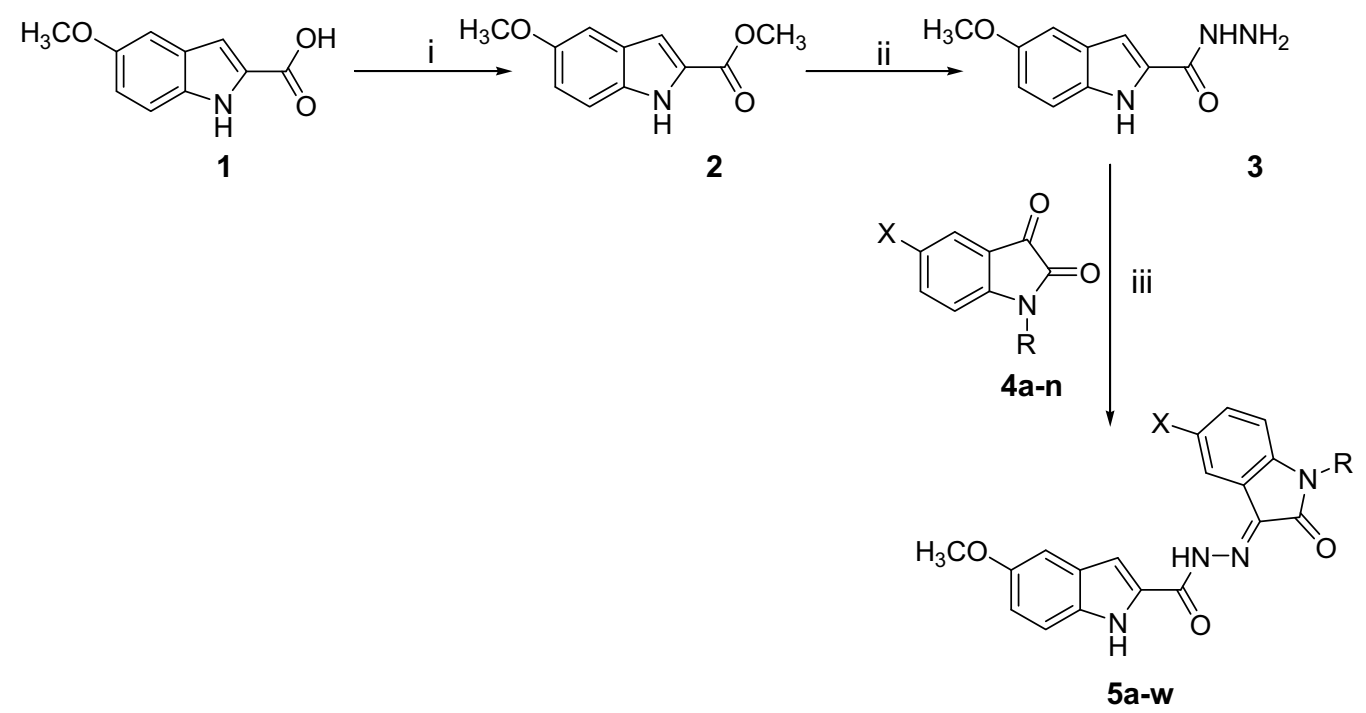

Scheme I Synthesis of compounds 5a-w. Reagents and conditions: (I) absolute methanol, $\mathrm{H}_{2} \mathrm{SO}_{4}$ (few drops), reflux, 4 hrs; (ii) absolute methanol, $\mathrm{H}_{2} \mathrm{~N}-\mathrm{NH} \mathrm{H}_{2} . \mathrm{H}_{2} \mathrm{O}$, reflux, 2 hrs; (iii) absolute ethanol, acetic acid (few drops), reflux, 4 hrs.

\begin{tabular}{|c|c|c|c|c|c|}
\hline Compound No. & $\mathbf{x}$ & $\mathbf{R}$ & Compound No. & $\mathbf{x}$ & $\mathbf{R}$ \\
\hline $5 \mathbf{a}$ & $\mathrm{H}$ & $\mathrm{H}$ & $5 \mathrm{~m}$ & $\mathrm{Cl}$ & $\mathrm{C}_{6} \mathrm{H}_{5}-\mathrm{CH}_{2}$ \\
\hline $5 b$ & $\mathrm{Br}$ & $\mathrm{H}$ & $5 n$ & $\mathrm{~F}$ & $\mathrm{C}_{6} \mathrm{H}_{5}-\mathrm{CH}_{2}$ \\
\hline $5 c$ & $\mathrm{Cl}$ & $\mathrm{H}$ & 50 & $\mathrm{OCH}_{3}$ & $\mathrm{C}_{6} \mathrm{H}_{5}-\mathrm{CH}_{2}$ \\
\hline $5 d$ & $\mathrm{~F}$ & $\mathrm{H}$ & $5 p$ & $\mathrm{H}$ & 4-F- $\mathrm{C}_{6} \mathrm{H}_{4}-\mathrm{CH}_{2}$ \\
\hline $5 e$ & $\mathrm{OCH}_{3}$ & $\mathrm{H}$ & $5 q$ & $\mathrm{Br}$ & 4-F- $\mathrm{C}_{6} \mathrm{H}_{4}-\mathrm{CH}_{2}$ \\
\hline $5 f$ & $\mathrm{H}$ & $\mathrm{CH}_{3}$ & $5 r$ & $\mathrm{Cl}$ & 4-F- $\mathrm{C}_{6} \mathrm{H}_{4}-\mathrm{CH}_{2}$ \\
\hline $5 g$ & $\mathrm{Br}$ & $\mathrm{CH}_{3}$ & $5 \mathrm{~s}$ & $\mathrm{~F}$ & 4- $-\mathrm{F}-\mathrm{C}_{6} \mathrm{H}_{4}-\mathrm{CH}_{2}$ \\
\hline $5 \mathrm{~h}$ & $\mathrm{Cl}$ & $\mathrm{CH}_{3}$ & $5 t$ & $\mathrm{H}$ & $4-\mathrm{Cl}-\mathrm{C}_{6} \mathrm{H}_{4}-\mathrm{CH}_{2}$ \\
\hline $5 \mathbf{i}$ & $\mathrm{F}$ & $\mathrm{CH}_{3}$ & $5 u$ & $\mathrm{H}$ & 4-CN- $\mathrm{C}_{6} \mathrm{H}_{4}-\mathrm{CH}_{2}$ \\
\hline $5 \mathbf{j}$ & $\mathrm{OCH}_{3}$ & $\mathrm{CH}_{3}$ & $5 v$ & $\mathrm{H}$ & 4- $\mathrm{CH}_{3}-\mathrm{C}_{6} \mathrm{H}_{4}-\mathrm{CH}_{2}$ \\
\hline $5 k$ & $\mathrm{H}$ & $\mathrm{C}_{6} \mathrm{H}_{5}-\mathrm{CH}_{2}$ & $5 w$ & $\mathrm{H}$ & $\mathrm{C}_{6} \mathrm{H}_{5}$ \\
\hline $5 \mathbf{I}$ & $\mathrm{Br}$ & $\mathrm{C}_{6} \mathrm{H}_{5}-\mathrm{CH}_{2}$ & & & \\
\hline
\end{tabular}

the preferred fragments at the isatin nitrogen, as they induced average growth inhibition of 96.0, 91.3, 94.5, 95.3, 91.8, 97.8 and 97.6\%, respectively. Also, halogen substitution at isatin C-5 is the favored substituent, except for compounds $\mathbf{5 0}$ and $\mathbf{5 w}$ which bear methoxy and hydrogen functionalities, respectively.

Compounds displaying an average growth inhibition of more than 90\% toward ZR-75, HT-29, and A-549 cell lines were subjected to median growth inhibitory concentration $\left(\mathrm{IC}_{50}\right)$ determination. Table 2 illustrates the $\mathrm{IC}_{50}$ values of compounds 5b, 5c, 5g-i, 5o, 5w and sunitinib toward ZR-75, HT-29 and A-549 cell lines. The most active candidates are 50 (bearing an $N$-benzylisatin moiety) and $\mathbf{5 w}$ (bearing an $N$ - phenylisatin moiety) with $\mathrm{IC}_{50}$ values of 1.69 and $1.91 \mu \mathrm{M}$, respectively, which are about fivefold and fourfold more potent than sunitinib $\left(\mathrm{IC}_{50}=8.11 \mu \mathrm{M}\right)$. Therefore, detailed pharmacological studies were carried on compound 5o, aiming to gain insight into the integrated pharmacological profile of this compound, as a representative for compounds 5a-w.

\section{Caspase $3 / 7$ activity}

The A-549 cell line was utilized to assess the apoptosisinducing potential of compound 5o. Activity assessment of compound 50 was carried out at concentrations equal to its $\mathrm{IC}_{50}$ for growth inhibition and at threefold above this concentration over a $2-48 \mathrm{hr}$ time course. Compound $\mathbf{5 0}$ 
Table I In vitro antiproliferative potential of compounds 5a-w and sunitinib against HT-29, ZR-75 and A-549 cell lines

\begin{tabular}{|c|c|c|c|c|}
\hline Compound No. & HT-29 & ZR-75 & A-549 & Average growth inhibition \% \\
\hline $5 \mathbf{a}$ & $10.2 \pm 6.3$ & $43.2 \pm 19.3$ & $14.4 \pm 5.2$ & 22.6 \\
\hline $5 \mathbf{b}$ & $96.2 \pm 4.8$ & $96.6 \pm 1.4$ & $95.2 \pm 6.2$ & 96.0 \\
\hline $5 c$ & $89.8 \pm 2.4$ & $88.8 \pm 7.0$ & $95.2 \pm 3.3$ & 91.3 \\
\hline $5 d$ & $52.5 \pm 9.4$ & $77.7 \pm 7.5$ & $62.5 \pm 13.4$ & 64.2 \\
\hline $5 e$ & $-7.3 \pm 30.1$ & $-37.4 \pm 8.9$ & $22.2 \pm 8.4$ & -7.5 \\
\hline $5 f$ & $82.5 \pm 11.9$ & $63.8 \pm 7.4$ & $89.2 \pm 6.4$ & 78.5 \\
\hline $5 g$ & $93.5 \pm 2.5$ & $94.4 \pm 3.9$ & $95.5 \pm 2.4$ & 94.5 \\
\hline $5 \mathrm{~h}$ & $92.3 \pm 2.1$ & $96.1 \pm 2.1$ & $97.5 \pm 1.0$ & 95.3 \\
\hline $5 \mathbf{i}$ & $92.9 \pm 0.9$ & $86.1 \pm 6.1$ & $96.5 \pm 3.8$ & 91.8 \\
\hline $5 j$ & $32.2 \pm 19.9$ & $54.6 \pm 22.3$ & $96.3 \pm 3.4$ & 61.0 \\
\hline $5 \mathbf{k}$ & $77.4 \pm 4.4$ & $46.0 \pm 20.1$ & $80.9 \pm 5.3$ & 68.1 \\
\hline 51 & $70.2 \pm 3.8$ & $53.8 \pm 16.5$ & $68.5 \pm 4.1$ & 64.2 \\
\hline $5 \mathrm{~m}$ & $69.9 \pm 6.0$ & $75.5 \pm 5.8$ & $70.1 \pm 4.0$ & 71.8 \\
\hline $5 n$ & $65.9 \pm 3.0$ & $73.7 \pm 3.7$ & $58.0 \pm 7.6$ & 65.9 \\
\hline 50 & $97.0 \pm 2.8$ & $96.5 \pm 2.8$ & $100.0 \pm 0.0$ & 97.8 \\
\hline $5 p$ & $80.8 \pm 6.3$ & $63.2 \pm 11.9$ & $81.9 \pm 2.2$ & 75.3 \\
\hline $5 q$ & $45.1 \pm 5.6$ & $35.9 \pm 2.1$ & $55.8 \pm 2.8$ & 45.6 \\
\hline $5 r$ & $40.3 \pm 10.2$ & $8.1 \pm 15.7$ & $56.1 \pm 5.7$ & 34.8 \\
\hline $5 s$ & $41.6 \pm 5.3$ & $52.7 \pm 12.0$ & $54.8 \pm 4.5$ & 49.7 \\
\hline $5 t$ & $84.1 \pm 7.2$ & $79.2 \pm 8.8$ & $100.0 \pm 0.0$ & 87.8 \\
\hline $5 u$ & $79.9 \pm 3.9$ & $82.6 \pm 12.4$ & $97.6 \pm 2.8$ & 86.7 \\
\hline $5 v$ & $84.4 \pm 9.1$ & $54.8 \pm 16.4$ & $89.2 \pm 4.8$ & 76.1 \\
\hline $5 w$ & $98.4 \pm 1.3$ & $94.8 \pm 2.1$ & $99.5 \pm 1.1$ & 97.6 \\
\hline Sunitinib & $59.5 \pm 2.3$ & $90.7 \pm 4.5$ & $85.7 \pm 2.7$ & 78.7 \\
\hline
\end{tabular}

Table 2 Antiproliferative inhibitory concentration $50 \%\left(\mathrm{IC}_{50}\right)$ values of compounds $\mathbf{5 b} \mathbf{b} \mathbf{5} \mathbf{c}, \mathbf{5 g}-\mathbf{i}, \mathbf{5 0}$, $\mathbf{5} \mathbf{w}$ and sunitinib toward A-549, ZR-75 and HT-29 cell lines

\begin{tabular}{|c|c|c|c|c|}
\hline \multirow[t]{2}{*}{ Compound No. } & \multicolumn{3}{|l|}{$I C_{50}(\mu M)$} & \multirow[t]{2}{*}{ Average $I C_{50}(\mu M)$} \\
\hline & A-549 & ZR-75 & HT-29 & \\
\hline $5 b$ & 23.8 & $15.0 \pm 10.36$ & $>30$ & $>22.9$ \\
\hline $5 c$ & 24.7 & $16.8 \pm 23.36$ & $16.0 \pm 16.07$ & 19.2 \\
\hline $5 g$ & $5.57 \pm 0.36$ & $5.29 \pm 1.08$ & $5.87 \pm 0.93$ & 5.6 \\
\hline $5 \mathrm{~h}$ & $6.08 \pm 0.86$ & $5.39 \pm 1.46$ & $6.29 \pm 1.69$ & 5.92 \\
\hline $5 \mathbf{i}$ & $18.60 \pm 66.69$ & 21.10 & $|2.80 \pm 2| .02$ & 17.5 \\
\hline 50 & $0.54 \pm 0.20$ & $1.58 \pm 2.97$ & $2.94 \pm 0.76$ & 1.69 \\
\hline $5 w$ & $1.53 \pm 0.33$ & $1.93 \pm 0.85$ & $2.27 \pm 0.26$ & 1.91 \\
\hline Sunitinib & $10.14 \pm 0.8$ & $8.31 \pm 2.4$ & $5.87 \pm 0.3$ & 8.11 \\
\hline
\end{tabular}

did not induce any substantial rise in caspase $3 / 7$ activity at any concentration or time point tested.

\section{Cell cycle influences}

The A-549 cell line was used to examine the influence of compound 50 on different features of the cell cycle progression. Activity assessment of compound 50 was conducted using immunofluorescent imaging of phosphorylated $\mathrm{Rb}$ protein as well as by quantification of the total DNA content of each cell to ascertain the phase of the cell cycle. Concentrations of less than $100 \mu \mathrm{M}$ to $50 \mathrm{nM}$ of compound 5o were utilized to assess its capability to influence cell cycle distribution as well as $\mathrm{Rb}$ phosphorylation. Figure 2 and Table 3 indicated that the total cell number was reduced with an IC50 value of $2.20 \mu \mathrm{M}$ after a $48 \mathrm{~h}$ treatment. Also, the levels of phosphorylated $\mathrm{Rb}$ protein were substantially decreased in a dose-dependent manner (Figure 3A). 


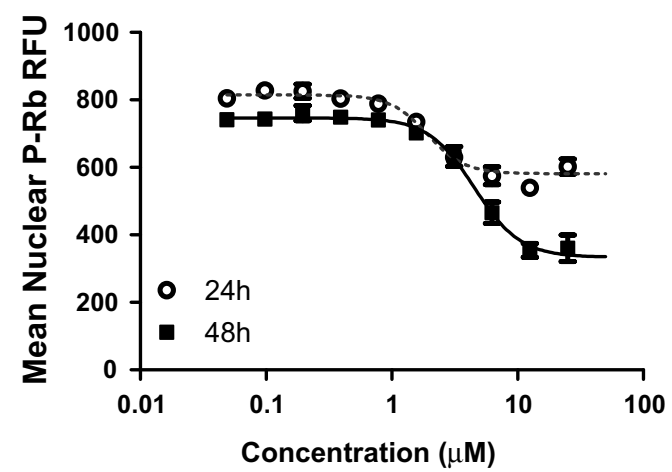

50
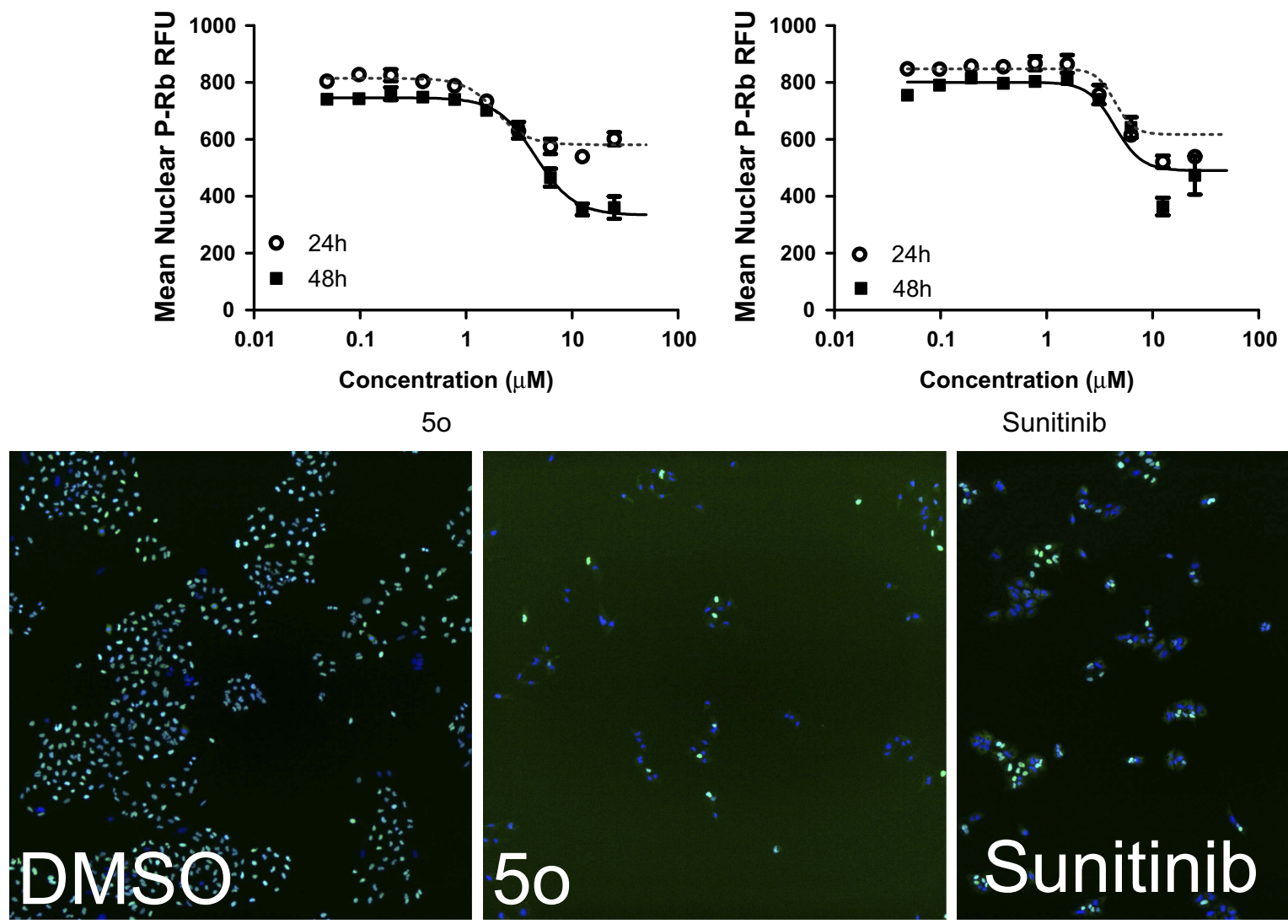

Sunitinib
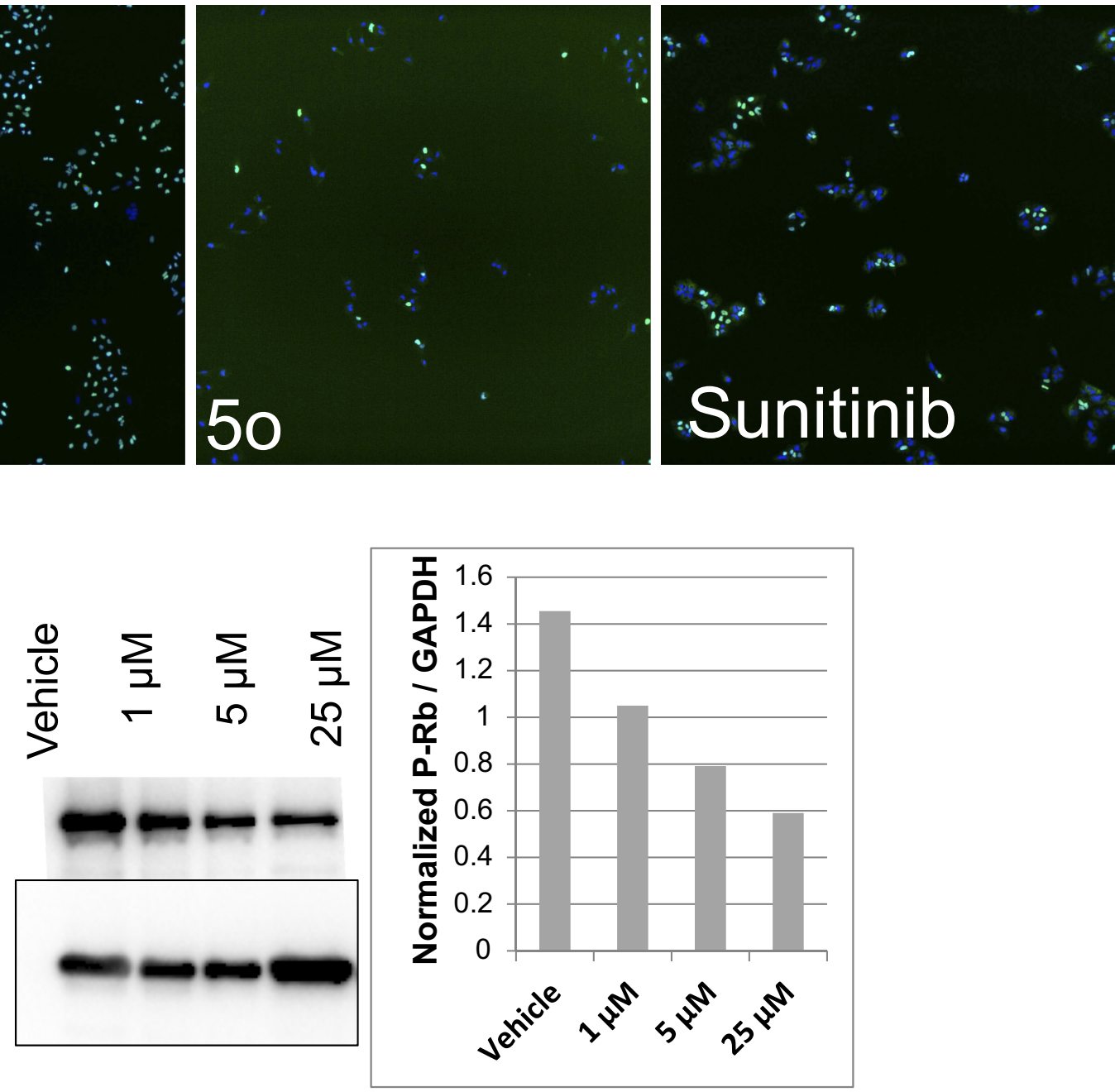

Figure 3 (A). Reduction of phosphorylated Rb protein by compound $\mathbf{5 0}$ and sunitinib. Levels of P-Rb in the nuclei were shown by immunofluorescence in cells treated with vehicle, 50 or sunitinib. Automated image analysis (Molecular Devices) was used to quantitate P-Rb changes and these are presented in the dose-response graphs for each compound after $24 \mathrm{hr}$ or $48 \mathrm{hr}$ treatment. (B) Western blot analysis of A-549 NSCLC cells treated with compound 5o shows the effect of on total cellular levels of P-Rb after $24 \mathrm{hr}$ treatment (left). Densitometric analysis of P-Rb normalized to GAPDH loading control is presented (right).

Abbreviations: GAPDH, glyceraldehyde-3-phosphate dehydrogenase; NSCLC, non-small cell lung cancer.

Independent experiments confirmed the effect of $\mathbf{5 0}$ to reduce $\mathrm{Rb}$ phosphorylation by Western blot analysis (Figure 3B). Moreover, compound 50 induced a reduction in the percentage of cells in the $\mathrm{S}$ and $\mathrm{G} 2 / \mathrm{M}$ phases of the cell cycle, with a concomitant rise in the G1 phase. These results suggest that part of the growth inhibition effect of compound 50 could be attributed to decreases in the progression rate of the cell cycle, with a concomitant reduction in proliferation. On the 
Table 3 Inhibitory concentration $50 \%\left(\mathrm{IC}_{50}\right)$ values for the decreases in the entire cell number and cell cycle influences of compound 50 and sunitinib

\begin{tabular}{|c|c|c|c|c|c|}
\hline \multirow[t]{2}{*}{ Compound No. } & \multicolumn{2}{|c|}{$\begin{array}{l}I C_{50}(\mu M) \text { for the decreases of } \\
\text { the entire cell number }\end{array}$} & \multicolumn{2}{|c|}{$\begin{array}{l}I_{50}(\mu M) \text { for the decrease of } \\
\text { Rb phosphorylation }\end{array}$} & \multirow[t]{2}{*}{ Cell cycle influences } \\
\hline & $24 \mathrm{hrs}$ & $48 \mathrm{hrs}$ & $24 \mathrm{hrs}$ & $48 \mathrm{hrs}$ & \\
\hline 5o & 10.47 & $2.20 \pm 1.30$ & $1.92 \pm 1.20$ & $3.78 \pm 1.10$ & GI increased and S, G2/M phases decreased \\
\hline Sunitinib & $12.54 \pm 9.82$ & $3.48 \pm 0.61$ & $3.18 \pm 0.07$ & $6.05 \pm 0.61$ & GI decreased and S, G2/M phases increased \\
\hline
\end{tabular}

contrary, sunitinib showed an increase in the percentage of cells in the $\mathrm{S}$ or $\mathrm{G} 2 / \mathrm{M}$ phases of the cell cycle, with a concomitant reduction in the G1 phase. Mitotic catastrophe followed by programmed death of cells containing aberrant or multiple nuclei may result from mitotic arrest due to arrest in the $\mathrm{G} 2$ phase of the cell cycle, which might represent a checkpoint blockade.

It should be mentioned that both compound $\mathbf{5 0}$ and sunitinib substantially reduced the extent of phosphorylated $\mathrm{Rb}$ protein in a dose-dependent fashion (Figure 3). Compound 5o exhibited $\mathrm{IC}_{50}$ values of 3.78 and $1.92 \mu \mathrm{M}$ after 48 and 24 hrs, respectively, which was roughly twofold more potent than sunitinib (Table 3). This may advance the assumption that the growth inhibitory potential of $\mathbf{5 0}$ could be attributed, in part, to its ability to inhibit cyclin-dependent kinases.

\section{Selectivity}

Three nontumorigenic cell lines (Table 4) were utilized to examine the growth inhibitory selectivity of compound 5o: IEC-6 cells which show morphologic and karyotypic characteristics of normal rat intestinal epithelial cells, ${ }^{37} \mathrm{MCF}-10 \mathrm{~A}$ cells which feature the characteristics of primary cultures of breast tissue with a dome formation ${ }^{38}$ and Swiss 3 t 3 fibroblasts derived from mice embryonic tissue which are both contact inhibited and nontumorigenic. ${ }^{39}$ A human non-small cell lung cancer (NSCLCA-549) cell line was used for comparison. Compound 50 was tested in quadruplicate at a maximum concentration of $25 \mu \mathrm{M}$ and 10 subsequent serially diluted concentrations.
Figure 4 and Table 4 indicate that compound 50 was able to inhibit cell growth in both tumor and normal cells. However, it showed threefold selectivity, while sunitinib displayed 1.4-fold selectivity.

\section{Activity against multidrug-resistant cancer cell line}

The growth inhibitory potential of compound $\mathbf{5 0}$ was tested against the sensitive lung cancer cell line NSCLC A-549 and the multidrug-resistant lung cancer cell line NCI-H69AR which expresses the ABCC1 efflux pump protein. Compound $\mathbf{5 0}$ was tested in quadruplicate at a maximum concentration of $25 \mu \mathrm{M}$ and 10 subsequent serially diluted concentrations.

Figure 5 and Table 5 indicate that compound 50 induced growth inhibition in both lung cancer cell lines, with an $\mathrm{IC}_{50}$ value of $0.9 \mu \mathrm{M}$ in A-549 cells, and being about 12-fold less sensitive toward the NCI-H69AR cell line. This result indicates that compound $\mathbf{5 0}$ might undergo efflux by the $\mathrm{ABCC} 1$ efflux pump protein. In contrast, sunitinib was only 1.9-fold less potent toward the NCI-H69AR cell line.

\section{Conclusion}

The molecular hybrids 5a-w were evaluated as new antiproliferative conjugates. Compounds 50 (bearing an $N$-benzylisatin moiety) and $\mathbf{5 w}$ (bearing an $N$-phenylisatin moiety) were the most active antiproliferative candidates, with $\mathrm{IC}_{50}$ values of 1.69 and $1.91 \mu \mathrm{M}$, respectively, being about fivefold and fourfold more potent than sunitinib $\left(\mathrm{IC}_{50}=8.11 \mu \mathrm{M}\right)$.

Table 4 Selectivity of $\mathbf{5 0}$ and sunitinib against nontumorigenic and tumor cell lines

\begin{tabular}{|l|l|l|l|l|l|}
\hline \multirow{2}{*}{ Compound No. } & \multicolumn{2}{|l|}{ IC $\mathbf{5 0}(\boldsymbol{\mu M})$} & \multirow{2}{*}{ Mean tumor selectivity } \\
\cline { 2 - 6 } & Intestine IEC-6 & Breast MCF-10A & Fibroblast Swiss 3t3 & NSCLCA-549 & \\
\hline 5o & $3.38 \pm 1.21$ & $1.69 \pm 1.12$ & $2.78 \pm 1.12$ & $0.86 \pm 121$ & 3.0 \\
Sunitinib & $4.56 \pm 0.54$ & $4.43 \pm 0.23$ & $4.07 \pm 0.75$ & 3.06 & 1.4 \\
\hline
\end{tabular}

Abbreviations: MCF, Michigan cancer foundation; 3T3, 3-day transfer, inoculum 3×105 cells; IEC, intestinal epithelial cell; IC 50 , inhibitory concentration 50\%; NSCLC, nonsmall cell lung cancer. 


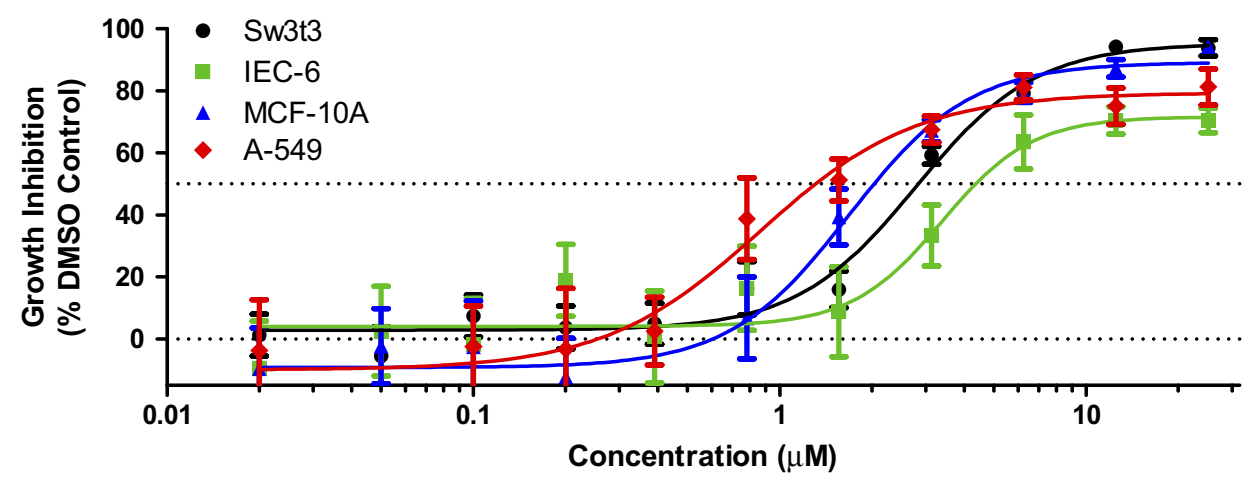

50

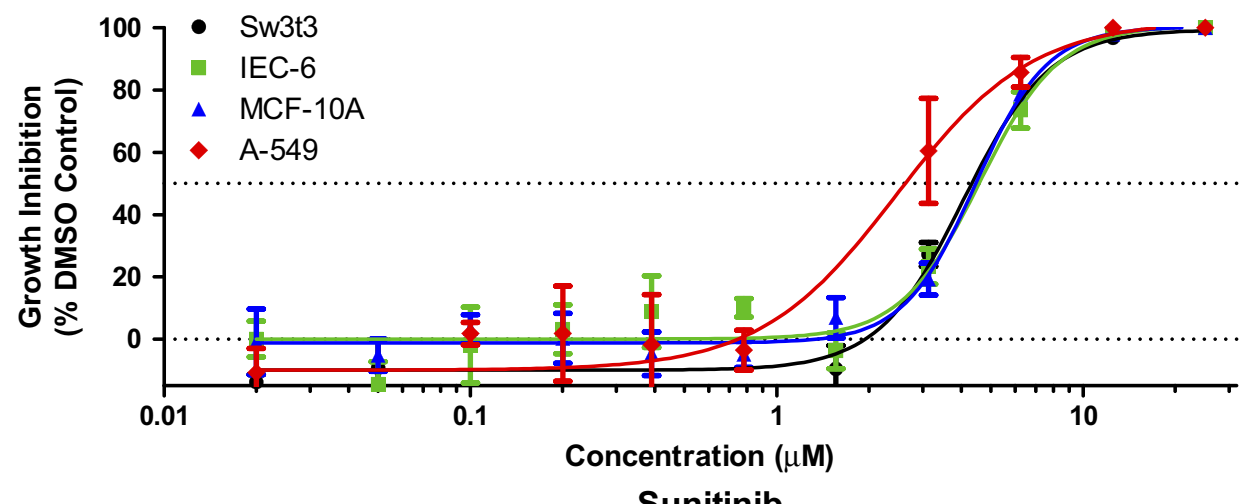

Figure 4 Selectivity characteristics of compound 50 and sunitinib.
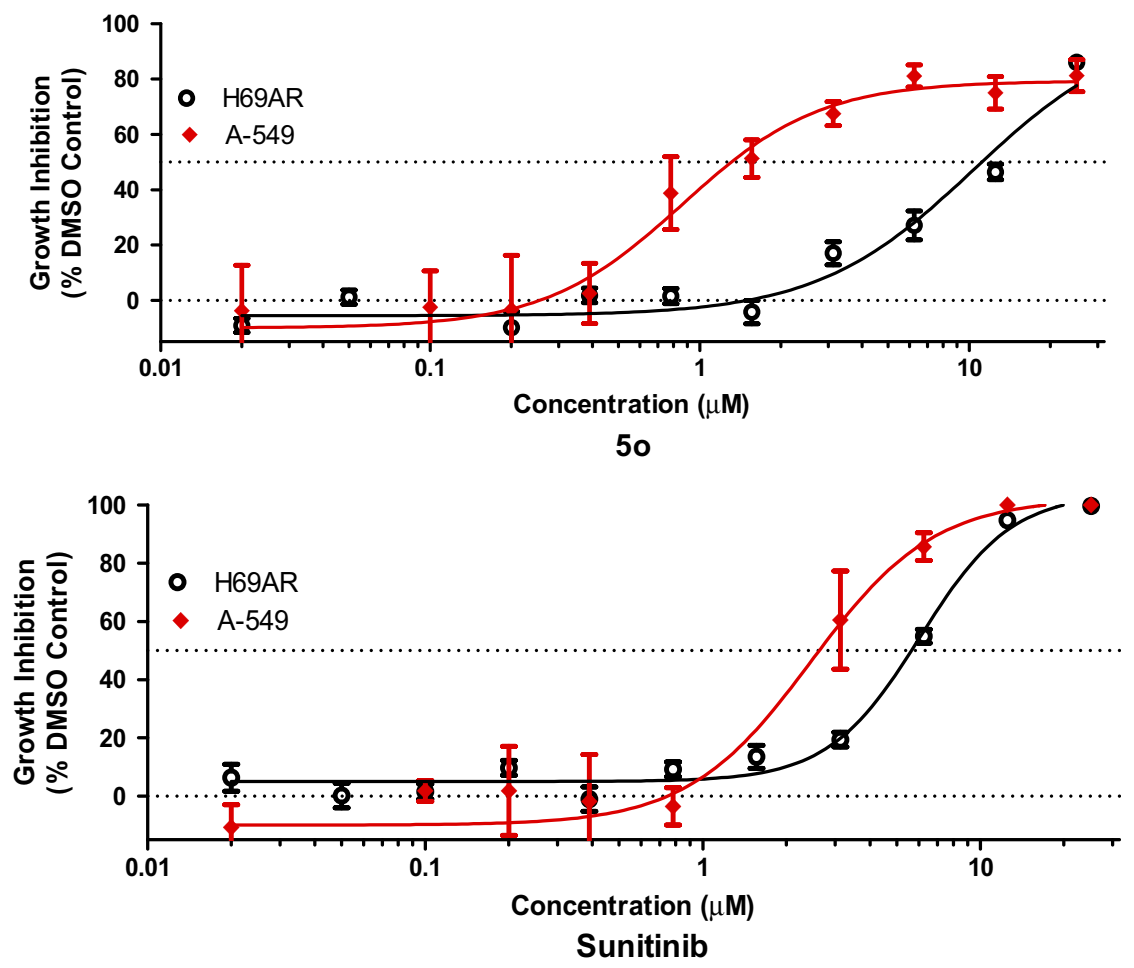

Figure 5 Activity of compound 50 and sunitinib against A-549 and NCl-H69AR cell lines. 
Table 5 Cancer cell growth inhibitory activity of compound $\mathbf{5 o}$ and sunitinib toward sensitive (A-549) and resistant ( $\mathrm{NCl}-\mathrm{H} 69 \mathrm{AR})$ cell lines

\begin{tabular}{|l|l|l|l|}
\hline \multirow{2}{*}{ Compound No. } & \multicolumn{2}{|l|}{ IC 5 Fo $(\mu \mathrm{M})$} & \multirow{2}{*}{ Fold resistant } \\
\cline { 2 - 3 } & A-549 & NCI-H69AR & \\
\hline 5o & $0.86 \pm 1.21$ & $10.4 \pm 1.82$ & 12.1 \\
Sunitinib & 3.06 & $5.8 \pm 0.52$ & 1.9 \\
\hline
\end{tabular}

Abbreviation: $\mathrm{IC}_{50}$, inhibitory concentration $50 \%$.

Detailed pharmacological studies were conducted on compound 5o, a promising antiproliferative candidate, for a better understanding of its pharmacological properties. Compound 50 did not show any significant rise in caspase $3 / 7$ activity at any concentration or time point tested. Moreover, it exhibited an increase in the G1 phase and a reduction in the $\mathrm{S}$ and $\mathrm{G} 2 / \mathrm{M}$ phases of the cell cycle, and it presented an $\mathrm{IC}_{50}$ value of $10.4 \mu \mathrm{M}$ toward the resistant NCI-H69AR cancer cell line. Furthermore, the extent of phosphorylated $\mathrm{Rb}$ protein was substantially decreased in a dose-dependent fashion by compound 50 which was further confirmed via Western blot analysis. This promotes the assumption that inhibition of cyclin-dependent kinases by compound 5o plays a role in its growth inhibitory potential.

Overall, the current investigation indicates that the new antiproliferative potential of the chemical entities 5a-w, compound 50 in particular, can support the development of new antiproliferative leads to be harnessed in preclinical studies of cancer chemotherapy.

\section{Acknowledgment}

The authors would like to extend their sincere appreciation to the Deanship of Scientific Research at King Saud University for its funding of this research through the Research Group Project no. RGP-196.

\section{Disclosure}

Dr Adam B Keeton is a shareholder for ADT Pharmaceuticals, LLC, outside the submitted work. Prof. Dr. Gary A Piazza is a co-founder, shareholder, and Chief Scientist for ADT Pharmaceuticals LLC and founder and president of PDEi Pharmaceuticals LLC. The authors report no other conflicts of interest in this work.

\section{References}

1. Jemal A, Siegel R, Ward E, et al. Cancer statistics, 2008. CA Cancer J Clin. 2008;58(2):71-96. doi:10.3322/CA.2007.0010
2. Sinha R, El-Bayoumy K. Apoptosis is a critical cellular event in cancer chemoprevention and chemotherapy by selenium compounds. Curr Cancer Drug Targets. 2004;4(1):13-28. doi:10.2174/156800 9043481614

3. Cozzi P, Mongelli N, Suarato A. Recent anticancer cytotoxic agents. Curr Med Chem-Anti-Cancer Agents. 2004;4(2):93-121.

4. Siegel RL, Miller KD, Jemal A. Cancer statistics, 2016. CA Cancer J Clin. 2016;66(1):7-30.

5. Barinaga M. From bench top to bedside. Science. 1997;278 (5340):1036-1039

6. Nabholtz J-M, Slamon D. New adjuvant strategies for breast cancer: meeting the challenge of integrating chemotherapy and trastuzumab (Herceptin). Semin Oncol. 2001;28(3):1-12.

7. Druker BJ, Sawyers CL, Kantarjian H, et al. Activity of a specific inhibitor of the BCR-ABL tyrosine kinase in the blast crisis of chronic myeloid leukemia and acute lymphoblastic leukemia with the Philadelphia chromosome. N Eng J Med. 2001;344(14):10381042.

8. Padma VV. An overview of targeted cancer therapy. BioMedicine. 2015;5(4):1-6.

9. Broekman F, Giovannetti E, Peters GJ. Tyrosine kinase inhibitors: multi-targeted or single-targeted? World J Clin Oncol. 2011;2(2):8093.

10. Topcul M, Cetin I. Endpoint of cancer treatment: targeted therapies. Asian Pac J Cancer Prev. 2014;15(11):4395-4403. doi:10.7314/ APJCP.2014.15.11.4395

11. Srivastava A, Pandeya S. Indole a versatile nucleus in pharmaceutical field. Int J Curr Pharm Rev Res. 2011;1(11):1-17.

12. Black W, Bayly C, Belley M, et al. From indomethacin to a selective COX-2 inhibitor: development of indolalkanoic acids as potent and selective cyclooxygenase-2 inhibitors. Bioorg Med Chem Lett. 1996;6 (6):725-730. doi:10.1016/0960-894X(96)00100-X

13. Flynn BL, Hamel E, Jung MK. One-pot synthesis of benzo[b]furan and indole inhibitors of tubulin polymerization. $J$ Med Chem. 2002;45(12):2670-2673. doi:10.1021/jm020077t

14. Leboho TC, Michael JP, van Otterlo WA, et al. The synthesis of 2and 3-aryl indoles and 1,3,4,5-tetrahydropyrano[4,3-b]indoles and their antibacterial and antifungal activity. Bioorg Med Chem Lett. 2009;19(17):4948-4951. doi:10.1016/j.bmcl.2009.07.091

15. Rapolu M, Kumanan R, Duganath N, et al. Synthesis, characterization and pharmacological screening of 2-methyl- $1 H$-indole-3-carboxylic acid [2-(2-substituted phenyl)-4-oxothiazolidin-3-yl]amide derivatives. Int J Chem Sci Appl. 2011;2(1):91-99.

16. Gollapalli M, Taha M, Ullah H, et al. Synthesis of Bis-indolylmethane sulfonohydrazides derivatives as potent $\alpha$-Glucosidase inhibitors. Bioorg Chem. 2018;80:112-120. doi:10.1016/j.bioorg.2018.06.001

17. Khan KM, Salar U, Afzal S, et al. Schiff bases of tryptamine as potent inhibitors of nucleoside triphosphate diphosphohydrolases (NTPDases): structure-activity relationship. Bioorg Chem. 2019;82:253-266. doi:10.1016/j.bioorg.2018.10.046

18. Anouar EH, Moustapha ME, Taha M, et al. Synthesis, molecular docking and $\beta$-glucuronidase inhibitory potential of indole base oxadiazole derivatives. Molecules. 2019;24(5):963. doi:10.3390/molecules 24050963

19. Attia MI, Witt-Enderby PA, Julius J. Synthesis and pharmacological evaluation of pentacyclic 6a,7-dihydrodiindole and 2,3-dihydrodiindole derivatives as novel melatoninergic ligands. Bioorg Med Chem. 2008;16(16):7654-7661. doi:10.1016/j.bmc.2008.07.012

20. Markl C, Attia MI, Julius J, et al. Synthesis and pharmacological evaluation of 1,2,3,4-tetrahydropyrazino[1,2-a]indole and 2-[(phenylmethylamino)methyl]- $1 H$-indole analogues as novel melatoninergic ligands. Bioorg Med Chem. 2009;17(13):4583-4594. doi:10.1016/j. bmc.2009.04.068

21. Markl C, Clafshenkel WP, Attia MI, et al. N-Acetyl-5-arylalkoxytryptamine analogs: probing the melatonin receptors for MT(1) -selectivity. Arch Pharm. 2011;344(10):666-674. 
22. Pandeya SN, Smitha S, Jyoti M, Sridhar SK. Biological activities of isatin and its derivatives. Acta Pharm. 2005;55(1):27-46.

23. Bhattacharya SK, Chakrabarti A. Dose-related proconvulsant and anticonvulsant activity of isatin, a putative biological factor, in rats. Indian J Exp Biol. 1998;36(1):118-121.

24. Pandeya SN, Sriram D, Nath G, DeClercq E. Synthesis, antibacterial, antifungal and anti-HIV activities of Schiff and Mannich bases derived from isatin derivatives and $N$-[4-(4'-chlorophenyl)thiazol-2yl]thiosemicarbazide. Eur J Pharm Sci. 1999;9(1):25-31.

25. Sridhar SK, Saravanan M, Ramesh A. Synthesis and antibacterial screening of hydrazones, Schiff and Mannich bases of isatin derivatives. Eur J Med Chem. 2001;36(7-8):615-625.

26. Banerjee $\mathrm{D}$, Yogeeswari $\mathrm{P}$, Bhat $\mathrm{P}$, et al. Novel isatinyl thiosemicarbazones derivatives as potential molecule to combat HIV-TB coinfection. Eur J Med Chem. 2011;46(1):106-121.

27. Vine KL, Indira Chandran V, Locke JM, et al. Targeting urokinase and the transferrin receptor with novel, anti-mitotic $N$-alkylisatin cytotoxin conjugates causes selective cancer cell death and reduces tumor growth. Curr Cancer Drug Targets. 2012;12(1):64-73.

28. Attia MI, Eldehna WM, Afifi SA, et al. New hydrazonoindolin-2ones: synthesis, exploration of the possible anti-proliferative mechanism of action and encapsulation into PLGA microspheres. PLoS One. 2017;12(7):e0181241.

29. Abdel-Aziz HA, Eldehna WM, Keeton AB, et al. Isatin-benzoazine molecular hybrids as potential antiproliferative agents: synthesis and in vitro pharmacological profiling. Drug Des Devel Ther. 2017;11:2333-2346.

30. Abdelhameed A, Bakheit A, Mohamed M, et al. Synthesis and biophysical insights into the binding of a potent anti-proliferative non-symmetric bis-isatin derivative with bovine serum albumin: spectroscopic and molecular docking approaches. Appl Sci. 2017;7 (6):617.
31. Eldehna WM, Al-Wabli RI, Almutairi MS. Keeton AB, et al. Synthesis and biological evaluation of certain hydrazonoindolin-2one derivatives as new potent anti-proliferative agents. $J$ Enzym Inhib Med Chem. 2018;33(1):867-878.

32. Almutairi MS, Zakaria AS, Ignasius PP, et al. Synthesis, spectroscopic investigations, DFT studies, molecular docking and antimicrobial potential of certain new indole-isatin molecular hybrids: experimental and theoretical approaches. J Mol Struct. 2018;1153:333-345.

33. Al-Wabli R, Zakaria A, Attia M. Synthesis, spectroscopic characterization and antimicrobial potential of certain new isatin-indole molecular hybrids. Molecules. 2017;22(11):1958.

34. Almutairi MS, Xavier S, Sathish M, et al. Spectroscopic (FT-IR, FTRaman, UV, ${ }^{1} \mathrm{H}$ and ${ }^{13} \mathrm{C}$ NMR) profiling and computational studies on methyl 5-methoxy-1H-indole-2-carboxylate: a potential precursor to biologically active molecules. $J$ Mol Struct. 2017;1133:199-210.

35. Eldehna WM, EL-Naggar DH, Hamed AR, et al. One-pot threecomponent synthesis of novel spirooxindoles with potential cytotoxic activity against triple-negative breast cancer MDA-MB-231 cells. $J$ Enzym Inhib Med Chem. 2018;33(1):309-318.

36. Eldehna WM, Abo-Ashour MF, Ibrahim HS, et al. Novel [(3-indolylmethylene) hydrazono] indolin-2-ones as apoptotic anti-proliferative agents: design, synthesis and in vitro biological evaluation. $J$ Enzym Inhib Med Chem. 2018;33(1):686-700.

37. Quaroni A, Wands J, Trelstad RL, Isselbacher KJ. Epithelioid cell cultures from rat small intestine. Characterization by morphologic and immunologic criteria. J Cell Biol. 1979;80(2):248-265.

38. Soule HD, Maloney TM, Wolman SR, et al. Isolation and characterization of a spontaneously immortalized human breast epithelial cell line, MCF-10. Cancer Res. 1990;50(18):6075-6086.

39. Todaro GJ, Green H. Quantitative studies of the growth of mouse embryo cells in culture and their development into established lines. $J$ Cell Biol. 1963;17:299-313.

\section{Publish your work in this journal}

Drug Design, Development and Therapy is an international, peerreviewed open-access journal that spans the spectrum of drug design and development through to clinical applications. Clinical outcomes, patient safety, and programs for the development and effective, safe, and sustained use of medicines are a feature of the journal, which has also been accepted for indexing on PubMed Central. The manuscript management system is completely online and includes a very quick and fair peer-review system, which is all easy to use. Visit http://www. dovepress.com/testimonials.php to read real quotes from published authors. 